\title{
Faktor Perilaku Cuci Tangan Pakai Sabun (CTPS) di SMP
}

\author{
Bambang Murwanto \\ Jurusan Kesehatan Lingkungan, Politenik Kesehatan Tanjungkarang \\ Email: bamurwanto@yahoo.co.id
}

\begin{abstract}
Factors of Handwashing Behavior with Soap in Junior Secondary Schools. Riskesdas (2013), Diarrhea is the number one cause of death in infants (31.4\%), children under five (25.2). Whereas in all age groups is a cause number four, or $13.2 \%$. Various factors affect the disease Diarrhoea among the factors of health behavior, especially the behavior of Handwashing with Soap that has been campaigned, both from the national level. As well as health offices District/City through PHC, especially in schools, including junior high school. The problem is to what extent the role of behavior Handwashing with Soap and the factors associated with it in school children. The purpose of this study was to determine the role of factors related to the behavior Handwashing with Soap, in junior high schools. This research method was quantitative observational with a cross sectional approach, with research time the months of April to July 2016. The study population was all students of SMP Negeri 1 Penengahan, South Lampung, 2016. Samples were taken by a proportional random sampling of 156 junior high school students. Subjects were children of class VII and Class VIII. The results of the study are of most variables are $\operatorname{good}(>50 \%)$, except for the variable perception and the Role of Health who are poor $(<50 \%)$, and the only variable values, Role of Teachers and the Role of Friends Schools that have a relationship significant overall Handwashing Behavior and Role of School Friend variable most dominant relationship.
\end{abstract}

Keywords: Behavior, Handwashing by Soap, Diarrhea

\begin{abstract}
Abstrak: Faktor Perilaku Cuci Tangan Pakai Sabun (CTPS) di SMP. Riskesdas 2013, penyakit Diare merupakan penyebab kematian nomor satu pada bayi $(31,4 \%)$, balita $(25,2)$, pada semua kelompok umur nomor empat $(13,2 \%)$. Berbagai faktor yang mempengaruhi penyakit Diare diantaranya faktor perilaku kesehatan terutama perilaku Cuci Tangan Pakai Sabun (CTPS) yang telah dikampanyekan, dari tingkat pusat maupun Dinas Kesehatan Kabupaten/Kota melalui Puskesmas, terutama di sekolah-sekolah, termasuk tingkat SMP. Permasalahannya adalah sampai seberapa jauh peranan perilaku CTPS dan faktor-faktor yang berhubungan dengannya pada anak sekolah. Tujuan penelitian, untuk mengetahui peranan faktor-faktor yang berhubungan dengan perilaku CTPS, di SMP. Metode Penelitian kuantitatif observasional dengan pendekatan Cross Sectional, waktu penelitian antara April-Juli 2016. Populasi seluruh murid SMP Negeri 1 Penengahan, Kec. Penengahan, Kabupaten Lampung Selatan Tahun 2016. Sampel diambil secara Proposional Random Sampling sebesar 156 orang murid. Subyek, adalah murid kelas VII dan Kelas VIII. Hasil penelitian, sebagian besar variabel bersifat baik $(>50 \%)$, kecuali variabel Persepsi dan Peranan Petugas Kesehatan yang bersifat buruk $(<50 \%)$, dan hanya variabel Nilainilai, Peranan Guru dan Peranan Teman Sekolah yang mempunyai hubungan bermakna terhadap Perilaku CTPS, dan variabel Peranan Teman Sekolah hubungan yang paling dominan.
\end{abstract}

Kata kunci: Perilaku, Cuci Tangan Pakai Sabun (CTPS), Diare

Pembangunan kesehatan yang merupakan bagian dari pembangunan manusia, mempunyai sasaran peningkatan derajat kesehatan yang berujung pada peningkatan Umur Harapan Hidup dan memberi konribusi pada pada hasil manusia seperti disebutkan di atas.

Salah satu permasalahan status kesehatan di atas adalah masalah penyakit Diare karena penyakit merupakan salah satu faktor kematian bayi dan balita di negara-negara berkembang termasuk Indonesia. Di Indonesia menurut Riskesdas 2013, Diare merupakan penyebab kematian nomor satu pada bayi $(31,4 \%)$ dan pada balita $(25,2 \%)$, sedangkan pada semua golongan umur penyebab kematian nomor empat $(13,2 \%)$. Menurut Riskesdas 2013, insiden diare pada semua kelompok umur mencapai 3,5\% (rentang menurut provinsi $1,6 \%-6,3 \%$ ), insiden diare pada balita sebesar $6,7 \%$ (rentang menurut provinsi 3,3\%-10,2\%). Sedangkan periode prevalence diare pada semua kelompok umur berdasarkan gejala sebesar $7 \%$ dan pada balita 10,2\%, (Kementerian Kesehatan, 2014). Walaupun periode prevalence diare pada semua kelompok 
umur berdasarkan gejala tingkat Propinsi Lampung mencapai 3,7\% (Kementerian Kesehatan, 2013), namun tingkat Incidence Rate (IR) kecenderungannya semakin meningkat.

Tahun 2005 sebesar 9,8/1000 penduduk menjadi 21,4/1000 penduduk tahun 2013. Sedangkan $I R$ Kabupaten Lampung Selatan tahun 2013 termasuk tertinggi kedua setelah Kab. Pesawaran, mencapai 32,9/1000 penduduk (Pemerintah Provinsi Lampung, 2013). Sedangkan IR menurut kasus Diare yang ditangani dari semua wilayah UPT Puskesmas rata-rata 2,5/100 penduduk, tertinggi di Wilayah UPT Puskesmas Penengahan 5,7 dalam 100 penduduk dan terendah di UPT Puskesmas Rawat Inap Ketapang (0,6/100 penduduk) tahun 2014 (Pemerintah Kabupaten Lampung Selatan; 2014).

Menurut HL. Blum determinan faktor yang cukup besar peranannnya adalah faktor perilaku kesehatannya (Blum, HL., 1983). Beberapa faktor-faktor perilaku yang beresiko terhadap terjadinya penyakit Diare adalah perilaku sanitasi (kesehatan lingkungan) yang merupakan bagian dari Perilaku Kesehatan (Notoadmodjo, S., 2010). Salah satu bentuk Perilaku Sanitasi yang dimaksud salah satunya Perilaku Cuci Tangan Pakai Sabun (CTPS). Perilaku Cuci Tangan Pakai Sabun merupakan Perilaku Hidup Bersih dan Sehat (PHBS) pada beberapa tatanan diantaranya Tatanan Rumah Tangga, Tatanan Sekolah, Tatanan Institusi Pelayanan Kesehatan, atau dengan kata lain Perilaku Cuci Tangan Pakai Sabun menjadi bentuk PHBS yang sangat penting.

Menurut Organisasi kesehatan Dunia (WHO) setiap tahunya 100 ribu anak Indonesia meninggal karena penyakit Diare, dan Cuci Tangan Pakai Sabun dapat mengurangi angka kejadian penyakit Diare sampai $47 \%$, namun tingkat kesadaran masyarakat untuk Cuci Tangan Pakai Sabun baru mencapai rata-rata 12\% (Kementerian Kesehatan RI, 2014). Program CTPS aplikasinya, lebih difokuskan di sekolah melalui proram Usaha Kesehatan Sekolah (UKS) dan yang terbanyak pada sekolah tingkat dasar (Sekolah Dasar). Penelitian ini dilakasanakan di tingkat sekolah menengah pertama atau SMP, karena untuk mengetahui (mengevaluasi) kegiatan CTPS ditingkat SD sampai seberapa pencapaian pada tingkat pasca SD atau di tingkat SMP. Selain itu masa SMP dalam masa pertmbuhan fisiologis dan psikologis yang pesat dan maksimal (Kementerian Kesehatan, 2014).

Permasalahan penelitian ini adalah masih rendahnya Perilaku Cuci Tangan Pakai Sabun (CTPS), dan bagaimana peranan faktor-faktor yang memengaruhinya yaitu Predesposing Factors (Faktor-faktor yang mempermudah), Enabling Factors (faktor-faktor pemungkin) dan Reinforcing Factors (Faktor-faktor penguat).

Tujuan penelitian, untuk mengetahui gambaran dan hubungan faktor-faktor determinan CTPS dengan CTPS pada anak sekolah SMP.

\section{METODE}

Penelitian ini bersifat kuantitatif observasional dan pendekatan Cross Sectional. Waktu penelitian, bulan April-Juli 2016, dengan lokasi di Kecamatan Penengahan, Kabupaten Lampung Selatan.

Populasi penelitian ini, seluruh murid SMP Negeri I Penengahan, kelas VII dan kelas VIII berjumlah 655 orang, dengan sampel 250 orang.Teknik pengambilan sampel, Proportional Random Sampling menurut kelas.

\section{HASIL}

\section{A. ANALISIS UNIVARIAT}

Tabel 1. Gambaran Distribusi Variabel Dependen dan Variabel Independen

\begin{tabular}{llr}
\hline \multicolumn{1}{c}{ Variabel } & Kriteria hasil & Hasil (\%) \\
\hline \multirow{2}{*}{ Perilaku CTPS } & Baik & 55,9 \\
& Buruk & 44,1 \\
\hline \multirow{2}{*}{ Pengetahuan CTPS } & Baik & 80 \\
& Buruk & 20 \\
\hline \multirow{2}{*}{ Sikap terhadap CTPS } & Mendukung & 46,5 \\
& K.Mendukung & 53,5 \\
\hline \multirow{2}{*}{ Perpsepsi terhadap CTPS } & Baik & 37 \\
& Buruk & 63 \\
\hline \multirow{2}{*}{ Citra Diri tentang CTPS } & Baik & 64,8 \\
\hline \multirow{2}{*}{ Nilai-nilai terhadap CTPS } & Buruk & 35,2 \\
\hline Kepercayaan tentang & Baik & 58 \\
CTPS & Baik & 42 \\
\hline Ketersedian Tempat cuci & Tersedia & 63,7 \\
Tangan & Tdk tersedia & 36,3 \\
\hline Kemudahan Mendapat & Mudah & 88 \\
Tempat CTPS & Sulit & 12 \\
\hline Peran Guru terhadap CTPS & Baik & 93 \\
& Buruk & 7 \\
\hline Peran Orang Tua terhadap & Baik & 56,4 \\
CTPS & Buruk & 43,4 \\
\hline Peran Petugas Kesehatan & Baik & 71 \\
terhadap CTPS & Buruk & 29 \\
\hline Peran Teaman-teman & Baik & 53,9 \\
\hline & Buruk & 70,7 \\
\hline
\end{tabular}

Dengan memperhatikan tabel 1, diketahui dari 12 Variabel Independen, sebagai besar (9 variabel) bernilai positif yaitu Pengetahuan, Citra Diri, Nilai-nilai, Kepercayaan, Ketersedian 
Tempat CTPS, Kemudahan mendapatkan CTPS, Peran Guru, Peran Orang Tua dan Peran Temanteman Sekolah dengan Range nilai persentase mulai dari $56,4 \%$ sampai $80 \%$.

Variabel independen yang nilai positifnya kurang dari $50 \%$, yaitu variabel Sikap, Persepsi dan Peran Petugas kesehatan, (37\% - 46,9 \%).

\section{B. ANALISIS BIVARIAT}

Tabel 2. Hubungan Variabel Independen dengan Variabel Dependen (CTPS)

\begin{tabular}{|c|c|c|c|}
\hline $\begin{array}{c}\text { Variabel } \\
\text { Bebas }\end{array}$ & $\begin{array}{c}\text { OR } \\
(95 \%)\end{array}$ & $P-V$ & Signifikansi \\
\hline Pengetahuan & $\begin{array}{r}1,482(0,804- \\
2,730) \\
\end{array}$ & 0,267 & $\begin{array}{c}\text { Tidak } \\
\text { Signifikan }\end{array}$ \\
\hline Sikap & $\begin{array}{r}1,519(0,923- \\
2,500) \\
\end{array}$ & 0,128 & $\begin{array}{c}\text { Tidak } \\
\text { Signifikan }\end{array}$ \\
\hline Persepsi & $\begin{array}{r}1,065(0,639- \\
1,777) \\
\end{array}$ & 0,910 & $\begin{array}{c}\text { Tidak } \\
\text { Signifikan }\end{array}$ \\
\hline Citra Diri & $\begin{array}{r}1,092(0,652- \\
1,830) \\
\end{array}$ & 0,838 & $\begin{array}{c}\text { Tidak } \\
\text { Signifikan } \\
\end{array}$ \\
\hline Nilai-nilai & $\begin{array}{r}1,772(1,072- \\
2,931)\end{array}$ & 0,035 & Signifikan \\
\hline Kepercayaan & $\begin{array}{r}1,310(0,785- \\
2,186) \\
\end{array}$ & 0,367 & $\begin{array}{c}\text { Tidak } \\
\text { Signifikan }\end{array}$ \\
\hline $\begin{array}{l}\text { Ketersedian } \\
\text { Tempat CTPS }\end{array}$ & $\begin{array}{r}1,895 \\
(0,885-4,055) \\
\end{array}$ & 0,141 & $\begin{array}{c}\text { Tidak } \\
\text { Signifikan } \\
\end{array}$ \\
\hline $\begin{array}{l}\text { Kemudahan } \\
\text { mendapatkan } \\
\text { Tempat CTPS }\end{array}$ & $\begin{array}{r}0,493(0,160- \\
1,340)\end{array}$ & 0,229 & $\begin{array}{c}\text { Tidak } \\
\text { Signifikan }\end{array}$ \\
\hline Peran Guru & $\begin{array}{r}1,791 \\
(1,085-2,956)\end{array}$ & 0,031 & Signifikan \\
\hline $\begin{array}{l}\text { Peran Orang } \\
\text { Tua }\end{array}$ & $\begin{array}{r}1,691(0,983- \\
2,908) \\
\end{array}$ & 0,077 & $\begin{array}{c}\text { Tidak } \\
\text { Signifikan }\end{array}$ \\
\hline $\begin{array}{l}\text { Peran Petugas } \\
\text { Kesehatan }\end{array}$ & $\begin{array}{r}0,774(0,472- \\
1,269) \\
\end{array}$ & 0,373 & $\begin{array}{c}\text { Tidak } \\
\text { Signifikan } \\
\end{array}$ \\
\hline $\begin{array}{l}\text { Peran Teman } \\
\text { Sekolah }\end{array}$ & $\begin{array}{r}2,493(1,436- \\
4,326) \\
\end{array}$ & 0,002 & Signifikan \\
\hline
\end{tabular}

Pada Tabel 2, mengambarkan secara ringkas hasil hubungan secara statistik antara

Tabel 3. Hasil Pemodelan Akhir Variabel yang Berhubungan dengan Perilaku CTPS

\begin{tabular}{lrrrrrrrr}
\hline Variabel & B & S.E & Wald & df & Sig & Exp(B) & \multicolumn{2}{c}{ 95\% C.I.for EXP(B) } \\
\cline { 5 - 9 } & & & & & & & Lower & \multicolumn{1}{c}{ Upper } \\
\hline Nilai & .521 & .271 & 3.690 & 1 & .055 & 1.684 & .989 & 2.864 \\
TCTPS & .403 & .410 & .967 & 1 & .325 & 1.496 & .670 & 3.340 \\
Rangu & .318 & .283 & 1.270 & 1 & .260 & 1.375 & .790 & 2.392 \\
Ranmansek & .702 & .307 & 5.217 & 1 & .022 & 2.018 & 1.105 & 3.687 \\
Rantu & .243 & .295 & .678 & 1 & .410 & 1.275 & .715 & 2.274 \\
\hline
\end{tabular}

Berdasarkan tabel 3 tersebut, diketahui ternyata setelah dilakukan analisis bersama terhadap variabel independen yang memenuhi kriteria analisis multivariat, diketahui hanya variabel nilai-nilai dan variabel peran teman disekolah yang secara statistik menunjukkan hubungan signifikan. vasiabel tergantung yaitu Perilaku Cuci Tangan Pakai Sabun (CTPS) dengan variabel-variabel bebas (Independen Variabel), dengan indikator nilai signifikansi yaitu $p$-value, dengan OR 95\%, bila nilai $p$-value $<0,05$ maka ada hubungan bermakna (Signifikan), dan bila nilai $p$-value > 0,05 maka tidak ada hubungan bermakna (Tidak Signifikan).

Berdasarkan tabel 2 di atas, diketahui hanya tiga variabel independen yang mempunyai hubungan bermakna (Signifikan) dengan perilaku CTPS murid SMP, yaitu Variabel Nilai-nilai, Peran Guru dan Peran Teman-teman Sekolah.

\section{ANALISIS MULTIVARIAT}

Dalam rangka mendapatkan gambaran hubungan beberapa variabel independen secara bersama-sama dengan satu variabel dependen (Hastono, SP., 2007), maka dilakukan teknik analisis Regresi Logistik Berganda dengan menggunaan Model Prediksi dan dilakukan secara bertahap yaitu analisis Seleksi Bivariat, dan Pemodelan Mutivariat.

Hasil akhir analisis multivariat dapat dilihat pada tabel 3 berikut :

\section{PEMBAHASAN}

\section{Perilaku Cuci Tangan Pakai Sabun}

Perilaku Cuci Tangan Pakai Sabun sebesar $55,9 \%$ tidaklah terlalu besar walaupun didukung sebagian besar variabel yang mempunyai nilai positif (atas $50 \%$ ), seperti juga terjadi SD Negeri 03 Kertajaya, Padalarang yaitu hanya 52,4\% (Saptiningsih, M., dkk, 2013). Bahkan pada anak Pra Sekolah di Wilayah Puskesmas Pajang, 
Surakarta hanya $21 \%$ (Listiyorini, W., dkk., 2012). Hasil Riskesdas 2013, perilaku cuci tangan yang benar juga masih rendah yaitu hanya 23,2\% (Pusdatin, 2015). Di Burundi juga hanya mencapai 66\% (Simetz, E., et al., 2016). Gerakan CTPS di sekolah juga tidak terlalu baik seperti yang terjadi di negara-negara Asia Tenggara yang di laporkan oleh Peltzer., K., dan Pengpid., S., (2014). Demikian pula di Dhaka, Bangladesh, kegiatan mencuci tangan saja hanya $12,6 \%$ dan menggunakan sabun hanya 3,7\% (Luby., SP., et al, 2010).

Di lingkungan pelajar pada universitas (mahasiswa) cuci tangan yang meggunakan sabun di Ghana hanya 20\% (Mariwah, S., et al., 2012), Di Kenya Cuci Tangan Pakai Sabun hanya 25\% (Schmitdt., WP., et al., 2009). Demikian pula terjadi di sekolah-sekolah pemerintah di pedesaan Andhra Pradesh India, bahwa tingkat pengetahuan murid tentang cuci tangan cukup tinggi, (>90\%), namun perilaku CTPS hanya 40\% (Takalkar, AA., et al., 2013).

Dari analisis Angket, rerata jawaban pertanyaan tidak maksimal yaitu 3. Rerata tertinggi pada pertanyaan 4 dan terendah pada pertanyaan 3. Hal ini sekaligus menggambarkan bahwa mencuci tangan pakai sabun hanya saat setelah Buang Air Besar (BAK), di negaranegara Asia Tenggara hanya 26,5\% (after toileting) (Peltzer., K., dan Pengpid., S., 2014).

Dengan demikian dapat disimpulkan bahwa masih relatif rendahnya Perilaku Cuci Tangan Pakai Sabun di sebagian besar komunitas seperti yang disebutkan di atas.

\section{Faktor-Faktor Predisposisi}

Bila dilihat satu-persatu pada Tabel 1 hanya variabel Sikap, Persepsi dan Peran Petugas Kesehatan yang mempunyai nilai negatif yaitu nilai yang bersifat positif hanya dibawah $50 \%$ (Persepsi baik 37\% dan Peran Petugas Kesehatan 47\%). Itu daat diasumsikan bahwa Perilaku Cuci Tangan Pakai Sabun yang hanya $55,9 \%$ didukung oleh sebagian besar variabel di atas (9 Variabel).

Dapat diasumsikan pula bahwa Perilaku Cuci Tangan Pakai Sabun seperti tersebut di atas disebabkan oleh perbedaan persepsi buruk yang mungkin juga disebabkan oleh kurangnya peran petugas kesehatan memberi penyuluhan tentang Cuci Tangan Pakai Sabun.

\section{Pengetahuan}

Tentang nilai rerata pertanyaan Pengetahuan Cuci Tangan Pakai Sabun belum maksimal, pada pertanyaan nomor 6 pada Angket
Pengetahuan, yaitu dengan nilai maksimal 1, yang menggambarkan bahwa setiap mencuci tangan tidak memakai sabun. Nilai ini cukup ekstrem tentang gambaran pengetahuan tentang Cuci Tangan Pakai Sabun. Demikian pula terjadi di Burundi Health Knowledge hanya sebesar $45 \%$ (Simetz, E., et all., 2016). Pengetahuan ini sangat penting peranannya karena dapat menjadi dasar (fondasi) dari perubahan perilaku Cuci Tangan Pakai Sabun di India dalam jangka panjang (Biran., A., et al., 2009). Tingkat pengetahuan tentang Cuci Tangan Pakai Sabun tersebut yang cukup tinggi (mencapai 80\%) tidak menjamin perilaku Cuci Tangan Pakai Sabun seperti terjadi di Nagolda, Andhra Pradesh, India (Takalkar, AA., et al., 2013).

\section{Sikap}

Pada Variabel Sikap yang di gambarkan secara rinci pada angket pertanyaan, secara rerata nilainya di atas 3 atau di atas nilai tengan 2,5, maka dapat disimpulkan bahwa sikapnya cenderung mendukung kurang mendukung atau negatif atas kegiatan Cuci Tangan Pakai Sabun. Demikian pula terjadi di Burundi Affective Beliefs mencapai 76\% (Simetz, E., et al., 2016). Demikian pula di Turki seperti yang dilaporakan oleh Tuzun., H. Et al (2015) bahwa 78\% responden menyatakan bahwa mencuci tangan sangat penting karena dapat mencegah penyakit. Sikap positif (positive attitudes) menjadi dasar bagi terbentuknya keyakinan yang positif yang diperlukan bagi perilaku cuci tangan (Burusnukul., P., dan Broz., CC., 2013).

\section{Persepsi}

Gambaran variabel Persepsi tentang Cuci Tangan Pakai Sabun tergambar pada tiga pertanyaan paka angket pertanyaan. Dari gambaran tersebut nampak bahwa pada nilai rerata pertanyaan nomor 1 dan 2 frekuensi relatif rendah dibandingkan pertanyaan nomor 3 yang mendapatkan nilai rerata yang paling tinggi. Apalagi pertanyaan nomor 1 merupakan pertanyaan negatif. Dengan nilai yang cukup variasi ini dapat simpulkan bahwa masih terjadi perbedaan persepsi tentang Cuci Tangan Pakai Sabun. Demikian pula terjadi di sekolah perawat East Tennessee State University USA, bahwa batasan yang jelas tentang Cuci Tangan Pakai Sabun yang baik dan benar belum mereka pahami secara menyeluruh (Berger, B., 2013). Kesalahpahaman tentang Cuci Tangan Pakai Sabun juga terjadi di kalangan pelajar/mahasiswa kedokteran di Malaysia (Al-Naggar, RA., AlJashamy, K., 2013). 


\section{Citra Diri}

Tentang variabel Citra Diri yang tergambar pada distribusi frekuensi pertanyaan angket, bahwa yang mempunyai nilai tertinggi adalah pertanyaan nomor 3 yaitu sebesar 3,7 , dibandingkan dengan nomor pertanyaan nomor 1 yaitu 3,1. Jika dibandingkan dengan hasil kumulatif nilai kuesioner dimana Citra Diri Baik mencapai 64,8\%. Disimpulkan bahwa Citra Diri lebih dilihat pihak luar yaitu teman-teman sekolahnya atau teman sebaya (peers review) cukup baik atau cukup tinggi. Cuci Tangan Pakai Sabun (CTPS) menjadai kebanggaan diri mereka dan merasa percaya diri ('pede') bila melakukan Cuci Tangan Pakai Sabun. Di Burundi juga tidak terlalu besar yaitu hanya sekitar $70 \%$ (Simetz, E., et al., 2016).

\section{Nilai-Nilai}

Variabel Cuci Tangan Pakai Sabun dilihat dari unsur Nilai-nilai, pada Distribusi Frekuensi hasil jawaban pada pertanyaan Angket, di bawah ini bahwa pertanyaan nomor yang paing tinggi frekuensinya yaitu 3,4 dan yang paling rendah nomor pertanyaan 3 yaitu 3,2 nilai frekuensinya. Jika dibandingka dengan hasil kumulatif yaitu Nilai-nilai yang bersifat positif hanya $58 \%$, maka hal ini menggambarkan bahwa nilai Cuci Tangan Pakai Sabun belum sepenuhnya sebagai nilai-nilai dalam kehidupan, karena gambaran frekuensi dari 3 pertanyaan masih sangat fluktuasi belum ada kecenderungan yang solid atau semua pertanyaan menuju kepada nilai frekuensi yang maksimal. Hal yang tidak jauh berbeda juga terjadi di Burundi, Social Norm hanya 69\% (Simetz, E., et al., 2016).

\section{Kepercayaan}

Gambaran distribusi frekuensi rerata pertanyaan pada angket pertanyaan tentang kepercayaan, dari empat nomor pertanyaan juga kecenderungannya masih fluktuatif belum kearah solid atau nilai nilai frekuensi yang maksimal. Dengan kemikian dapat disimpulkan bahwa kegiatan Cuci Tangan Pakai Sabun belum sepenuhnya sebagai suatu kepercayaan yang melekat pada keyakinannya masing-masing. Terbentuknya keyakinan/kepercayaan yang positif yang diperlukan bagi perilaku cuci tangan (Burusnukul., P., dan Broz., CC., 2013) dan upaya peningkatan keyakinan/kepercayaan merupakan upaya peningkatan perilaku Cuci Tangan Pakai Sabun di Bangladesh (Halder. A, et $a l, 2010)$. Tingkat kepercayaan/ keyakinan yang tinggi juga terjadi kalangan perawat (Aiello., AE., et al., 2009).

\section{Faktor-faktor Pemudah (Enabling)}

\section{Tempat Cuci Tangan}

Pada gambaran Distribusi Frekuensi nomor pertayaan Angket tentang variabel Tempat Cuci Tangan, dapat disimpulkan bahwa tempat cuci tangan selain di kantin yang cenderung solid yaitu di kelas dan di rumah, sedangkan di kantin masih relatif sulit mendapatkan tempat cuci tangan. Tempat mencuci tangan (handwashing stations) yang pada daerah yang sulit mendapat air dapat dengan menggunakan dengan hand sanitizer tanpa air (waterless) dan dapat mengurangi kontaminasi dengan kotoran, seperti tisu basah, dsb. (Luby., SP., et al, 2010), walaupun sulit diterapkan dengan menggunakan sabun.

\section{Kemudahan Mendapatkan Tempat Cuci Tangan}

Tentang variabel Kemudahan mendapatan tempat cuci tangan (aksesibiliti) pada distribusi frekuensi nomor pertanyaan Angket, disimpukan bahwa sekalipun tersedia tempat cuci tangan di sekolah namun lebih sulit mendapatkannya daripada di rumah, yang secara kuantitatif Tempat Cuci Tangan 88\%, nilai ini cukup besar, dengan kata lain responden seolah-olah tidak merasa kesulitan untuk mendapatkan tempat cuci tangan, dan belum tentu pakai sabun. Sulitnya mendapatkan tempat cuci tangan sangat tergantung pada ada atau tidaknya tersedia tempat cuci tangan (handwashing stations), (Baker., KK., et al., 2014).

Beberapa gambaran yang cenderang sama di beberapa tempat, seperti di India bahwa sesederhana tempat cuci tangan atau tempat penampungan air dan hanya diberi kran saja (water storage container with tap) sudah dapat mengurangi tingkat absensi sakit murid, dan meminimalkan resiko penyebaran infeksi demam tifus (Tambekar, DH., Shirsat, SD., 2012). Berkaitan tempat cuci tangan ini di Bogota, Columbia, baru-baru ini renovasi program di sekolah untuk memperoleh perubahan perilaku cuci tangan, mendapatkan dukungan dari faktor lingkungan yaitu para murid, guru, orang tua, pihak sekolah, petugas kesehatan, organisasi swasta maupun pemerintah (Lopez-Quintero, C., dkk., 2009). Dari reviu beberapa penelitian tentang cuci tangan menggambarkan bahwa kekurangan fasilitas air bersih dan sanitasi untuk harus menjadi perhatian oleh manajemen sekolah, birokrat, lintas sekotal dan organisasi sosial kemasyarakatan serta menjadi focus penelitian mendatang (Jasper, C., dkk., 2012). 


\section{Faktor-faktor Pendorong (Reninforcing)}

\section{Peran Guru}

Peran Guru terhadap kegiatan Cuci Tangan Pakai Sabun pada, maka bila di sandingkan dengan data distribusi rerata pertanyaan, dapat disimpulkan kecenderunganya sudah relatif solid, sehingga saat disimpulkan Variabel Peran Guru dapat dikakatan lebih positif. Di Negara Bagian Utah, Amerika Serikat, peran guru sangat penting melakukan Cuci Tangan Pakai Sabun karena menjadi contoh dan sekaligus menjadi proses edukasi tentang higiene perseorangan khususnya tentang kebersihan tangan (Snow., M., et al., 2008), juga dapat mendorong teknik cuci tangan yang tepat untuk mencegah penyebaran penyakit dalam kelas (Redmond, T., 2009).

\section{Peran Orang Tua}

Mengenai variabel Peran Orang Tua pada distribusi frekuensi nomor pertanyaan seperti Gambar 11, bila disandingkan dengan distribusi rerata pertanyaan, kecenderngan masih belum solid, sehingga disimpulkan bahwa Peran Orang Tua belum positif. Padahal peran orang tua sebagai sumber informasi cuci tangan pada anak sekolah cukup tinggi yang terjadi di Kecamatan Selat, Kapuas, (Setyautami, T., et al., 2012).

\section{Peran Petugas Kesehatan}

Variabel Peran Petugas Kesehatan pada distribusi frekuensi nomor pertanyaan Angket, maka kecederungannya masih belum solid sehingga dapat disimpulkan bahwa Peran Petugas Kesehatan belum positif. Demikian pula yang di laporkan oleh Barrett, R., dan Randle, J., (2008). Peran petugas kesehatan memang tidak terlalu menonjol karena bersifat pengawasan dan pembinaan (supervised) terhadap guru yang menjadi ujung tombak perubahan perilaku cuci tangan yang positif (Setyautami, T., et al., 2012).

\section{Peran Teman di Sekolah}

Pada variabel Peran Teman Sekolah pada distribusi frekuensi nomor pertanyaan Angket, maka kecederungannya solid sehingga dapat disimpulkan bahwa Peran Tema Sekolah sangat positif. Reandahnya peran petugas kesehatan dalam Cuci Tangan Pakai Sabun bukan saja dalam komunitas sekolah tetapi contohnya terjadi pada penjamah makanan di Pantai Kedongan, Bali yaitu 34\% (Sundari, DWH, dkk., 2014).

\section{Analisis Variabel yang Berhubungan}

Menindaklanjuti analisis univariat di atas, maka analisis bivariat mendapatkan hanya tiga variabel saja yang mempunyai hubungan bermakna terhadap Perilaku Cuci Tangan Pakai Sabun yaitu Nilai-nilai, Peran Guru dan Peran Teman-teman sekolah. Seperti juga Pengetahuan dan Sikap dengan Perilaku Cuci Tangan Pakai Sabun tidak ada hubungan yang bermakna seperti terjadi di SD Negeri 03 Kertajaya, Padalarang (Saptiningsih, M., dkk, 2013). Peran guru dan orang tua dalam gerakan cuci tangan juga terjadi di Bogota, Columbia seperti yang dilaporkan oleh Lopez-Quintero, C., dkk., (2009).

\section{Analisis Multivariat (Variabel yang Dominan)}

Memperdalam analisis Bivariat untuk mencari variabel mana paling dominan dari ketiga variabel di atas, didapat Variabel Peran Teman Sekolah. Hal ini dapat berarti memberi peran paling besar pada pembentukan Perilaku Cuci Tangan pakai Sabun. Peranan teman sekolah memegang peranan penting sebagai agen perubahan perilaku kesehatan dalam suatu komunitas ini juga terjadi di Cina (Bowen, A., dkk., 2007). Pada studi lainnya, menggambarkan peranan anak sekolah memotivasi teman kelasnya dalam merubah perilaku (Rohde JE., Sadjimin T., 1980), demikian pula terjadi di Bogota, Columbia tentang peran murid (LopezQuintero, C., dkk., 2009). Peranan pihak sekolah atau kampus di Turki dalam program pendidikan kesehatan masyarakat sangat diharapkan (Ergin., A., et.all, 2011).

Peranan sekolah dalam meningkatkan motivasi perubahan perilaku semua murid dan petugas sekolah perlu di pertimbangkan untuk program cuci tangan kedepannya (Blanton, E. Et. All., 2010). Perlunya peranan institusi sekolah di Turki dalam program Cuci Tangan Pakai Sabun melalui Promosi Kesehatan di sekolah juga ditekankan oleh Tuzun., H. Et al (2015).

Kurangnya peranan petugas kesehatan yang dirasakan oleh para reponden yang digambarkan pada variabel di atas serta peranan teman sekolah sebagai teman sebaya (peers) yang cukup dominan maka peranan kebijakan Dinas Kesehatan dalam progam UKS seharusnya difokuskan pada peningkatan perilaku cuci tangan pakai sabun dengan mengupayakan peranan teman sekolah. Berarti pembinaan peranan kader UKS di tingkat SMP yaitu Palang Merah Remaja (PMR), dan lembaga organisasi ekstra kurikuler lainnya seperti Kepramukaan bekerjasama dalam program peningkatan Perilaku Cuci Tangan Pakai Sabun. Pada akhirnya peranan promosi kesehatan tentang Cuci Tangan Pakai Sabun merupakan strategi yang efektif untuk meningkatkan kebiasaan 
perilaku higienis dan meningkatkan derajat kesehatan (Bowen., A., et al., 2013). Di China mengadopsi kerangka Promosi Kesehatan di Sekolah (Health Promotion School/HPS) kedalam kurikulum yang didukung oleh lingkungan sekolah dan pemerintah Lee, et al, 2008 dalam Redmond, T., (2009).

\section{SIMPULAN}

1. Perilaku Cuci Tangan Pakai Sabun (CTPS) di SMP sudah cukup baik (mencapai 55,9\%).

2. Sembilan variabel bernilai positif (Pengetahuan, Citra Diri, Nilai-nilai, Kepercayaan, Ketersedian Tempat CTPS, Kemudahan mendapatkan CTPS, Peran Guru, Peran Orang Tua dan Peran Teman Sekolah) atau kecenderungannya ke positif.

3. Terdapat tiga variabel mempunyai nilai positifnya kurang dari $50 \%$, yaitu variabel Sikap, Persepsi dan Peran Petugas kesehatan, atau kecenderungannya negatif.

\section{SARAN}

1. Kepada Dinas Kesehata Lampung Selatan dan UPT Puskesmas Rawat Inap dalam pembinaan UKS di SMP Negeri 1 Penengahan pada khsususnya dan Sekolahsekolah lainnya agar memfokuskan pembinaan Perilaku Cuci Tangan Pakai Sabun melalui pembinaan organisasiorganinasi kesiswaan baik intra maupun ekstra kurikuler yang menjangkau peranan teman sekolah sebagai teman sebaya (peer friends) untuk bersinerji dalam upaya peningkatan Perilaku Cuci Tangan Pakai Sabun, seperti PMR, Kepramukaan, OSIS, dan organisasi-organisasi teman sebaya lainnya.

2. Kepada lembaga penelitian atau peneliti lain, agar melanjutkan penelitian ini dengan memperdalam peranan teman sekolah dalam upaya peningkatan Perilaku Cuci Tangan Pakai Sabun dan variabel-variabel lain yang belum diukur pada penelitian seperti keberadaan tempat cuci tangan (Handwashing Station), pengetahuan, sikap dan perilaku Cuci Tangan Pakai Sabun para guru, dsb.

\section{DAFTAR PUSTAKA}

Al-Naggar, RA., Al-Jashamy, K. 2013. Perceptions and Barriers of Hands Hygiene Practice Among Medical Science Students in a Medical School in Malaysia. The International Medical Journal Malaysia, Vol. 12 Number 2, Dec 2013, Hal. 11-14.

Biran., A., et al. 2009. The Effect of Soap Promotion and Hygiene Education Campaign on Handwashing Behaviour in Rural India: Cluster Randomised Trial. Tropical Medicine and International Health, Vol. 14, No. 10. Hal. 1303-1314.

Blum HL. 1983. Expanding Health Care Horizons, From a General Systems Concept of Heath To a National Health Policy. Second Edition, Third Party Publishing Company, Oakland.

Bowen., A., et al. 2013. Sustained Inprovement in Handwashing Indicators More Than 5 Years After a Cluster-Randomized, Community-Based Trial of Handwashing Promotion in Karachi, Pakistan. Tropical Medicine and International Health, Vol. 18, No. 3, March 2013, Hal. 259-267.

Berger, B. 2013. "Hand Hygiene Perceptions of Student Nurses.". Undergraduate Honors

Theses.Paper 176.http://dc.etsu.edu/ honors/176 (Diakses pada 26 Oktober 2016)

Hastono, SP. 2007. Analisis Data Kesehatan. Fakultas Kesehatan Masyarakat. Jakarta: Universitas ndonesia.

Halder., A, et al. 2010. Observed Hand Cleanliness and Other Measures of Handwashing Behavior in Rural Bangladesh. BMC Public Health 2010 10545, Hal. 1-9.

Jasper, C., dkk. 2012. Water and Sanitation in Schools:A Systematic Review of the Health and Educational Outcomes. International Journal of Environmental Research and Public Health, 9, h. 2772-2787.

Kementerian Kesehatan. 2014. Profil Kesehatan Indonesia Tahun 2013. Jakarta: Kementerian Kesehatan RI.

Listiyorini, W., dkk. 2012. Hubungan Antara Kebiasaan Mencuci Tangan Anak Praksekolah Dengan Kejadian Diare di Wilayah Kerja Puskesmas Pajang, Surakarta. http:/eprint.ums.ac.id/22549, 11 Juli 2016, 20.31.

Lopez-Quintero, C., dkk. 2009. Hand Washing Among School Children in Bogota, 
Columbia. American Journal of Public Health, January 2009, Vol. 99, No.1, h. 94-101.

Luby., SP., et al. 2010. A CommunityRandomised Controlled Trial promoting Waterless Hand Sanitizer and Handwashing With Soap, Dhaka, Bangladesh. Tropical Medicine and International Health, Vol. 15 No. 12 December 2010, Hal. 1508-1516.

Mariwah, S., et al. 2012. The Impact of Gender and Physical Environment on The Handwashing Behaviour of University Student. Tropical Medicine and International Health, Vol. 17, No. 4, April 2012, Hal. 447-454.

Notoadmodjo, S. 1993. Metodelogi Penelitian Kesehatan. Jakarta: Rineka Cipta.

Pemerintah Provinsi Lampung. 2014. Profil Kesehatan Lampung Provinsi Lampung Tahun 2013. Lampung: Dinas Kesehatan, Pemerintah Provinsi Lampung.

Peltzer., K., dan Pengpid., S. 2014. Oral and Hand Hygiene Behaviour and Risk among In-School Adolescents in Four Southeast Asian Countries. Int. J. Environ. Res. Public Health 2014, 11, Hal. 2780-2792.

Pusdatin. 2015. Perilaku Cuci Tangan Pakai Sabun di Indonesia. Infodatin, Jakarta: Kemenkes RI.

Redmond, T. 2009. The Teacher's Role in Enforcing Hand Washing Techniques Among-Age School in The Midst of the Pandemic. A Journal of College and Health Professions, Vo. 10, Issue I, Spring 2009, Columbus State University, Hal.3941

Saptiningsih, M, dkk. 2013. Faktor-faktor Yang Berhubungan Degan Perilaku Mencuci
Tangan Pada Anak Sekolah Dasar Negeri 03 Kertajaya Padalarang; http://eprints. undip.ac.id/42527/1/Bab_I-IV.pdf (Diakses pada 14 Juli 2016).

Setyautami, T., et al. 2012. Proper Hand Washing Practice Among Elementary School Student in Selat Sub-District, Indonesia. Journal of Public Health and Development, Vol. 10, No. 2, May-August 2012, Hal. 3-20.

Schmitdt., WP., et al. 2009. Determinan of Handwashing Pratice in Kenya, The Role of Media Exposure, poverty and Infrastructure. Tropical Medicine and International Health, Vol. 14 No. 12 December 2009, Hal. 1534-1541.

Seimetz, E., et al. 2016. The Inluence of Contextual and Psychosocial Factors of Handwashing. Am. J. Trop. Med Hyg, 93(6), Hal. 1407-1417.

Takalkar, AA., et al. 2013. Hand Hygiene: Perception and Practices of School Going Children from Rural Goverment Schools of Nalgonda, Andhra Pradesh. Int J Med Health Sci, April 2013, Vol 2, Issue 2-2, Hal. 154-160.

Tambekar, DH., Shirsat, SD. 2012. Minimization of Illness Absenteeism in Primary School Students Using Low-Cost Hygiene Intervetion. Online Journal of Health and Allied Science, Vol. 11, Issue 2; Apr-Jun 2012, h. 1-4.

Tuzun., H. et al. 2015. Turkey Handwashing Survey: Suggetion for Taking the Ecological Model into Better Consideeration. Environ. Health Prev. Med. (2015) 20, Hal. 325-331. 